\title{
The effect of artificial support material existence on removal of organic and nutrient in laboratory scale using plug flow reactor (PFR)
}

\author{
Sarah Aphirta ${ }^{1, *}$, Prayatni Soewondo ${ }^{2}$, Nida Maisa Zakiyya ${ }^{2}$, Dyah Wulandari Putri ${ }^{2}$, and Barti Setiani Muntalif ${ }^{2}$ \\ ${ }^{1}$ Environmental Engineering Master Program, Faculty of Civil and Environmental Engineering, Institut Teknologi Bandung \\ ${ }^{2}$ Program Study of Environmental Engineering, Faculty of Civil and Environmental Engineering, Institut Teknologi Bandung
}

\begin{abstract}
Artificial support material was examined to determine the removal capacity of organic pollutants and nutrients on laboratory scale using PFR system. The experiment was performed using artificial water with similar characteristics to Cikapayang River in three PFRs of $10.78 \mathrm{~L}$. The PFRs were made of PVC pipes filled with an inert chemical substrate as an artificial support material. The process of pollutants removal in the PFR relies on a biological layer (biofilm) grown on the surface of the material support. Three type of C:N:P ratio used in this study were 30:15:1, 75:25:2, and 180:35:3. The results showed that the maximum removal efficiency of TSS, TN, TP, and COD in the preliminary tests were $85 \%, 87 \%, 71 \%$ and $79 \%$, respectively. Moreover, the maximum water absorption capacity result was up to $30.8 \%$. Organic substrate removal rate compared with first order and Strover-Kincannon substrate removal models prediction. The best fit model for this experiment was Stover-Kincannon model, with the average correlation coefficient up to $90 \%$ for all of the three reactors. SEM analysis shown that the microorganisms shape is coccus with the average size of $5 \mu \mathrm{m}$.
\end{abstract}

\section{Introduction}

Population growth in urban areas triggers the development of various activities, cause pollution, especially anthropogenic pollutants. The emergence of pollution without integrated prevention and repair efforts will have a very serious negative impact on environmental degradation. The growth of population will increase the consumption of clean water which has implications for increasing the amount of wastewater and also the risk of effluent disposal into rivers, lakes or the sea, so that wastewater treatment is needed in order to reduce contaminants which enter the environment [1].

In general, cities in Indonesia still lack the facilities and infrastructure for wastewater treatment which is characterized by the lack of a centralized and integrated wastewater management system. Nowadays, centralized wastewater management system has only been implemented in 11 (eleven) cities in Indonesia with a low service coverage [2]. About $90 \%$ of wastewater in Indonesia is channeled through drainage network in the city without being treated and ends up in the river as a receiving water body. Inorganic compounds (ammonia, nitrate and phosphate) which trigger the growth of aquatic biota, contribute to the phenomenon of eutrophication in receiving water bodies that contain effluent wastewater [1].

It is known that Bandung, especially the area of South Bandung, such as Dayeuh Kolot and Majalaya, experiences heavy floods which regularly occur every year. Bandung is still implementing the drainage function with a combination system, in addition to functioning as a drainage of rainwater, it also functions as a domestic sewage system that drains liquid and solid waste from households. Due to the topography of the Bandung basin and the meandering and low elevation of the Citarum River, there are areas that are critical of the threat of standing water, namely the Bojongsoang and Tegallular Areas [2].

Artificial support material technology offers practical and sustainable solutions to meet the challenges of water resource management. The raw material for this artificial support material comes from volcanic lava which is $100 \%$ natural and environmentally friendly material, has a very large porosity which is indicated by water retention capacity of $92 \%$ with a weight of $120 \mathrm{~kg} / \mathrm{m}^{3}$. This technology function as a biopore and infiltration well and has a high permeability and can be produced in different densities. As a filter, this artificial support material has a hydraulic conductivity value of $7 \mathrm{~mm} / \mathrm{sec}$ [3]. Previous research located on agricultural land in Netherland has

\footnotetext{
Corresponding author: aphirtasarah@gmail.com
} 
shown the potential for very effective removal of $90 \%$ organic material, $42 \%$ total phosphate, and $40 \%$ total nitrogen using material support compared to straw [3].

This method could be adapted in Indonesia. While the government urge on Citarum River revitalization and improving water quality in receiving water bodies, attached growth biological treatment using artificial support material in the drainage system or water bodies become an alternative technology to support sustainable management of natural resources in Indonesia and help the implementation of environmentally drainage concept.

This study focused on the lab scale experiment by using artificial water similar to Cikapayang river as one of the tributary of Citarum River. Organic removal would be evaluated by mathematical model, while the artificial support material would be observed to get to know the attached biomass characteristics.

\subsection{Theoritical develoment}

Mathematical models are used to test hypotheses, determine the importance of relationships between variables, guide experimental designs, and to evaluate experimental results [4].

In this study, first order substrate removal and StroverKincannon model were used to find out the model of the biological process in the reactor.

\subsubsection{First order sustrate removal model}

The rate of change of substrate concentration in the system by assuming a first order model for substrate removal can be stated as follows [5]:

$$
-\frac{d S}{d t}=\frac{Q S_{0}}{V}-\frac{Q S}{V}-k_{1} S
$$

During pseudo-steady-state conditions, the rate of change of substrate concentration due to accumulation ($\mathrm{dS} / \mathrm{S}$ ) is ignored and the above calculation can be modified as follows:

$$
\frac{S_{0}-S}{H R T}=k_{1} S
$$

The value of $\mathrm{k}_{1}$ can be obtained by plotting $\left(\left(\mathrm{S}_{0}-\mathrm{S}\right) / \mathrm{HRT}\right)$ versus $\mathrm{S}$ in equation (2).

\subsubsection{Strover-Kincannon model}

In this model the rate of substrate use is expressed as a function of the rate of organic load by kinetic monomolecules for biofilm reactors such as RBC or biological filters. This model can be stated as follows [6]:

$$
\frac{d S}{d t}=\frac{U_{\max } \times\left(Q \times S_{0} / V\right)}{K_{B}+\left(Q \times S_{0} / V\right)}
$$

Where $(\mathrm{dS} / \mathrm{dt})$, the rate of use of the substrate is defined in equation (3).

$$
\frac{d S}{d t}=\frac{Q S_{0}}{V} \times\left(S_{0}-S\right)
$$

Equation (5) is obtained from linearization of equation (4) as follows:

$$
\frac{V}{Q \times\left(S_{0}-S\right)}=\frac{K_{B}}{U_{\max }} \frac{V}{Q \times S_{0}}+\frac{1}{U_{\max }}
$$

\section{Methods}

\subsection{Artificial water}

Water characteristics used in this study were rainwater which is potentially polluted by gray water waste, where the water used is artificially made with the addition of chemicals so that its characteristics resemble water in the Cikapayang River in 2018.

Three variations of the $\mathrm{C}: \mathrm{N}: \mathrm{P}$ ration used in this study were $30: 15: 1,75: 25: 2$, and $180: 35: 3$, the composition of artificial wastewater can be seen in Table 1 .

The synthetic wastewater was prepared using glucose $\left(\mathrm{C}_{6} \mathrm{H}_{12} \mathrm{O}_{6}\right)$ as the carbon source, $\mathrm{NH}_{4} \mathrm{Cl}$ as nitrogen source, $\mathrm{KH}_{2} \mathrm{PO} 4$ as phosphorus source, clay for TSS.

\begin{tabular}{|c|c|c|c|c|}
\hline \multirow{2}{*}{$\begin{array}{l}\text { Parameter } \\
\text { COD }\end{array}$} & \multirow{2}{*}{$\begin{array}{c}\text { Source } \\
\mathrm{C}_{6} \mathrm{H}_{12} \mathrm{O}_{6}\end{array}$} & \multicolumn{3}{|c|}{$\begin{array}{c}\text { Concentration } \\
\text { Variation } \\
(\mathrm{mg} / \mathrm{L}) \\
\end{array}$} \\
\hline & & 30 & 75 & 180 \\
\hline $\begin{array}{l}\text { Total } \\
\text { Nitrogen }\end{array}$ & $\mathrm{NH}_{4} \mathrm{Cl}$ & 15 & 25 & 35 \\
\hline $\begin{array}{l}\text { Total } \\
\text { Phosphate }\end{array}$ & $\mathrm{KH}_{2} \mathrm{PO}_{4}$ & 1 & 2 & 3 \\
\hline TSS & Clay & & 90 & \\
\hline VSS & $\begin{array}{l}\text { Activated sludge } \\
\text { from aeration tank }\end{array}$ & & 2000 & \\
\hline
\end{tabular}

As for VSS, some addition of active microorganisms was taken from activated sludge of domestic WWTP in Bandung Jayakarta Hotel.

Table 1. Artificial wastewater composition

\subsection{Reactor configuration}

This experiment was carried out with a laboratory scale reactor made of PVC pipe with a volume of $10.78 \mathrm{~L}$ and a dimension of $1.4 \mathrm{~m}$ (length) $\times 0.165 \mathrm{~m}$ (diameter). PVC pipe along the $1.4 \mathrm{~m}$ with a diameter of 6 inches or equivalent to $165 \mathrm{~mm}$ halved in parallel, installed 6 (six) $1 \mathrm{~cm}$ porous bulkhead. Dimensions of artificial material support of $3.0 \mathrm{~cm} \times 3.0 \mathrm{~cm} \times 3.0 \mathrm{~cm}$ with a volume of 27 $\mathrm{cm}^{3}$ results in the amount of media (material support) of 14 media per sampling point by taking into account the fill fraction below $70 \%$, and placed at 7 (seven) sampling points along the reactor. Placement of media in the reactor is carried out by stratification and there is no variation in the placement or amount of media for the 3 (three) typical reactors. The scheme of the experimental system in the form of a reactor configuration in this study can be seen 
in Figure 1. Flowrate variations and reactor loads can be seen in Table 2.

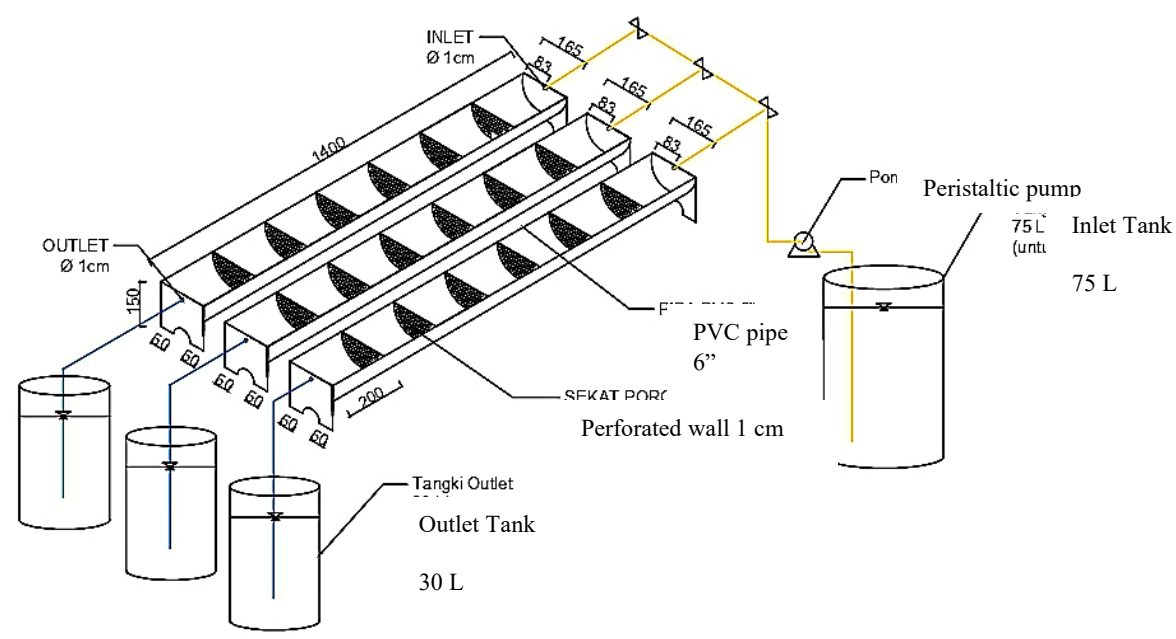

Figure 1. Schematic view of experimental system

Table 2. . Flowrate variation and reactor loads

\begin{tabular}{|c|c|c|c|c|c|c|c|c|}
\hline \multirow{2}{*}{ Reactor } & \multirow{2}{*}{$\begin{array}{c}\text { Flowrate } \\
(\mathrm{L} / \mathrm{sec})\end{array}$} & \multirow{2}{*}{$\begin{array}{l}\text { Velocity } \\
(\mathrm{cm} / \mathrm{sec})\end{array}$} & \multirow{2}{*}{ Pump } & \multicolumn{5}{|c|}{ Loading (kg/L.day) } \\
\hline & & & & COD & $\mathbf{T N}$ & TP & TSS & VSS \\
\hline \multirow{3}{*}{ I } & \multirow{3}{*}{0.00104} & \multirow{3}{*}{0.014} & \multirow{9}{*}{$\begin{array}{l}120 \\
\mathrm{rpm}\end{array}$} & 0.00025 & 0.00013 & 0.000008 & & \\
\hline & & & & 0.00063 & 0.00021 & 0.000017 & 0.00075 & 0.01667 \\
\hline & & & & 0.00150 & 0.00029 & 0.000025 & & \\
\hline \multirow{3}{*}{ II } & \multirow{3}{*}{0.000366} & \multirow{3}{*}{0.005} & & 0.000088 & 0.000044 & 0.0000029 & \multirow{3}{*}{0.00026} & \multirow{3}{*}{0.00587} \\
\hline & & & & 0.00022 & 0.000073 & 0.0000059 & & \\
\hline & & & & 0.00053 & 0.000103 & 0.0000088 & & \\
\hline \multirow{3}{*}{ III } & \multirow{3}{*}{0.000139} & \multirow{3}{*}{0.002} & & 0.00003 & 0.000017 & 0.0000011 & \multirow{3}{*}{0.00010} & \multirow{3}{*}{0.00223} \\
\hline & & & & 0.00008 & 0.000028 & 0.0000022 & & \\
\hline & & & & 0.00020 & 0.000039 & 0.0000033 & & \\
\hline
\end{tabular}

\subsection{Bioreactor operation}

The initial stage of this experiment was a preliminary test of artificial material support with a sampling time of 0 hours, 3 hours, 24 hours, and 90 hours using an artificial wastewater composition without activated sludge; assuming no microorganisms growth occured.

In the mean time, seeding was done in a 75 liter tank. The source of microorganisms comes from aeration tanks in a domestic WWTP.

Bacterial concentrations $\left(\mathrm{C}_{\mathrm{B}}\right)$ measured gravimetrically as VSS. In this process the substrate used is $\mathrm{C}, \mathrm{N}$, and $\mathrm{P}$ with a ratio of 100: 5: 1 [7]. At this stage the measurements taken were the measurement of VSS and COD up to steady state marked by changes in COD concentration of $\pm 10 \%$ every 24 hours. It was expected that when the COD concentration decreases, the $C_{B}$ concentration is $\geq 2000 \mathrm{mg} / \mathrm{l}$.

When running a continuous system reactor with the assumption that there is growth of microorganisms in the media, artificial waste control and seeded microorganisms are put into the reactor without treatment. The research process was carried out with 3 (three) variations of load and discharge. Load variations are indicated by variations of discharge controlled by a peristaltic pump. Load variations include variations in organic load (COD) and nutrients $(\mathrm{N}$ and $\mathrm{P})$. After reaching steady state conditions, the measured parameters are COD, VSS, $\mathrm{pH}$, $\mathrm{DO}$, temperature, $\mathrm{TN}$, and TP, nitrate, and nitrite.

In the final stage of the experiment, the water absorption capacity was determined using volumetric methods. SEM analysis were performed to see the biofilm texture, growth of microorganisms, and the structure of the media.

\subsection{Water absorption capacity test}

For attach growth process, material specification is one of the influential factor. The required characteristic of the media also depends on the process. In this study, the media meant to be in the water flow. For this case, its sustainability to be used in water bodies should be determined to reduce inundation. 
By using water absorption capacity variable, the absorption capacity media could be calculated. The test was performed by placing a block of media (size $3 \mathrm{~cm} \times$ $3 \mathrm{~cm} \times 3 \mathrm{~cm}$ ) in a $100 \mathrm{~mL}$ of measuring cup. The residence time of the media were varied in 4 variations: 5 minutes, 3 hours, 24 hours, and 90 hours. After the residence time, media was taken to get the remaining volume. The percentage of absorbed water in the media was counted as the water absorption capacity.

\section{Results and discussion}

\subsection{Preliminary test}

This preliminary test is intended to see the ability of artificial material support in removing organic pollutants and nutrients for a specified time of 3 hours, 24 hours, and 90 hours with the assumption that there is no growth of biomass in the system.

\subsubsection{Total nitrogen removal}

The removal efficiency of total nitrogen in the preliminary test was up to $87 \%$ with the lowest removal efficiency of $30 \%$. Elimination of total nitrogen in three variations of total influent concentration of nitrogen can be seen in Figure 2. Elimination of nitrogen compounds in bioreactors can only occur using simultaneous nitrification and denitrification (SND) by denitrifying heterotrophic and nitrifying autotrophic bacteria [8]. In the case of an aerobic PFR system, the total nitrogen removal cannot be done thoroughly. In this experiment, influentconcentration and HRT value affect the efficiency of total nitrogen removal in the system. In a HRT condition of 90 hours with an influent concentration of 25 $\mathrm{mg} \mathrm{TN} / 1$, the highest removal efficiency was $87 \%$. This can be due to the increase in HRT resulting in an increase in biofilm thickness due to a decrease in pressure so the nitrification process was starting to develop denitrification process with anoxic environmental conditions.

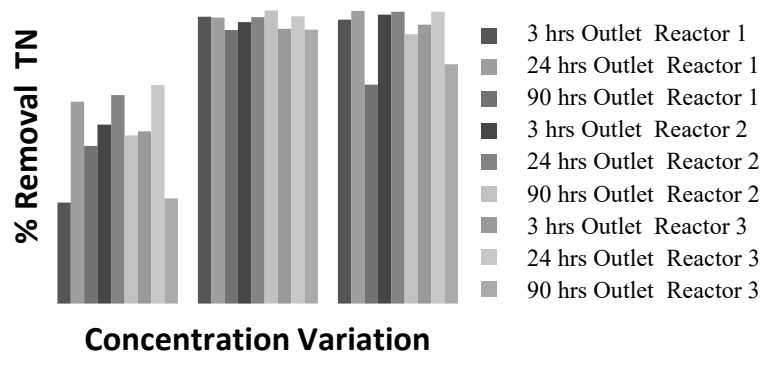

Figure 2. Total nitrogen removal in preliminary test

\subsubsection{Total phosphate removal}

The efficiency of total phosphate removal (Figure 3) in the preliminary test obtained the highest yield of $71 \%$ and the lowest yield of $15 \%$. The biological process of phosphate removal occurs in two stages; anaerobic and aerobic. The highest removal efficiency of total phosphate was found in 24-hour HRT with an influent concentration of $1 \mathrm{mg} \mathrm{TP} / 1$. The presence of phosphate compounds in the system in a dissolved form, so that the removal mechanism of total phosphate compounds can be through absorption, which according to [8] release of orthophosphate and accumulation of polyhydroxybutyrate (PHB) is achieved through absorption of phosphate in the aerobic area. In embedded growth systems, it is not possible to control the total phosphate removal in the system, as the value of solids retention time (SRT) is long enough and the release of biomass cannot be controlled. In the attached growth system, long SRT can cause a polyphosphateaccumulating organisms (PAO) accumulation, and the released orthophosphate is at a much higher level than influent concentration.

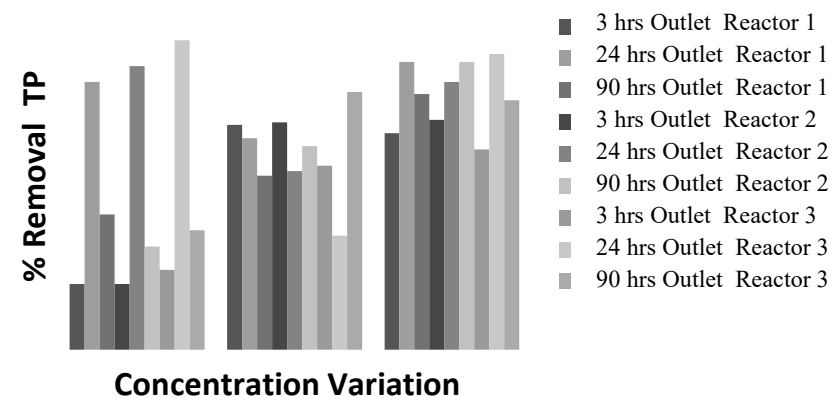

Figure 3. Total phosphate removal in preliminary test

\subsubsection{Organic removal (COD)}

The COD removal efficiency (Figure 4 (a) and (b)) in the preliminary test obtained the highest removal of $79 \%$ and the lowest removal of $30 \%$. In the biological processing, organic matter acts as a basic energy needed by microorganisms. COD removal in the system can occur due to absorption mechanism so that it is absorbed into the pores of the media and absorption by aerobic microorganisms and psychochemical adsorption on the surface of biological floc. The highest efficiency of COD removal was found in HRT 3 hours with an influent concentration of $75 \mathrm{mg} \mathrm{COD} / 1$. In this case, assuming there is no growth of microorganisms in the system, the removal mechanism occured was the organic molecules absorption into the fiber media. The COD removal process in the PFR system that showed a fluctuating results with a fairly good trend. Increasing and decreasing the value of COD removal at each point in the PFR is considerably becaused of the ability of the media to absorb organic compounds in dissolved form and flow velocity in the system. The media was placed in a randomly distributed system with a uniform amount, but the position of the media in the system also affects the absorption ability in absorption, where the media is spread evenly in the observation point will absorb more organic molecules that pass through the media. 


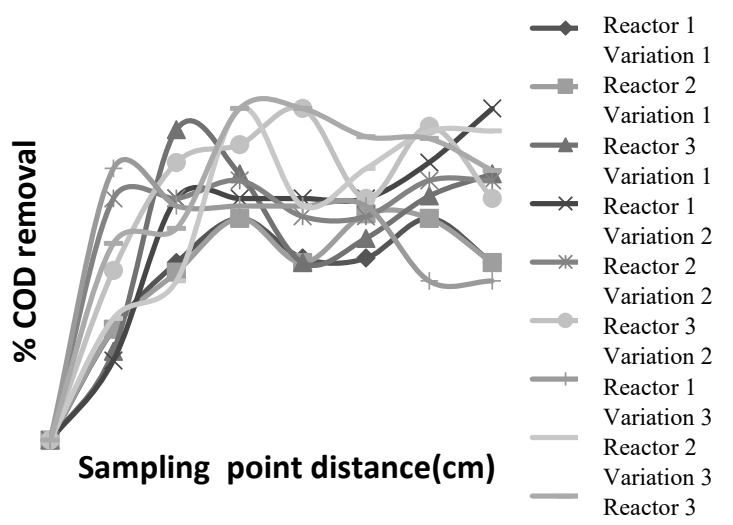

(a)

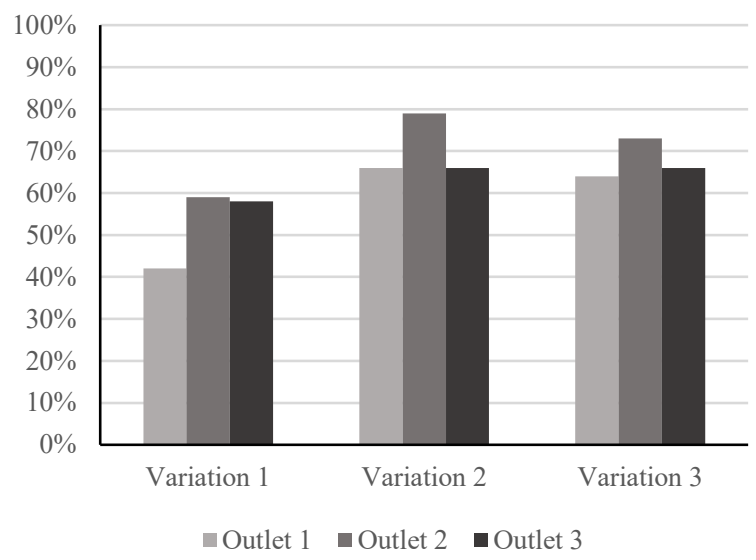

(b)

Figure 4. COD Removal in preliminary test in (a) different sampling point $(\mathrm{cm})(\mathrm{b})$ three variation of HRT

\subsubsection{Total suspended solid removal}

The TSS removal efficiency (Figure 5 (a) and (b)) in the preliminary test reached $85 \%$ with the minimum value of $71 \%$. The removal mechanism of suspended particles could be occured by filtration by the media inside the system. TSS parameters are compounds with the highest success rate in the preliminary test of the ability to remove pollutants by artificial support material. Filtered TSS particles then identified through changes in color and texture of artificial support material, where an $85 \%$ allowance is found in HRT 3 hours with an influent concentration of $90 \mathrm{mg} \mathrm{TSS} / 1$ showing the media in reactor 1 is yellowish according to the TSS source used ie soil clay, and slam starts to form. The results of previous study [9] showed that the longer contact time in the filtration process, the better the diffusion and adhesion of adsorbate molecules takes place.

\subsection{Aerobic continuous running system}

The performance of removal of organic content in the PFR system under steady-state conditions can be seen in Table 3. The COD removal results indicate a fairly good

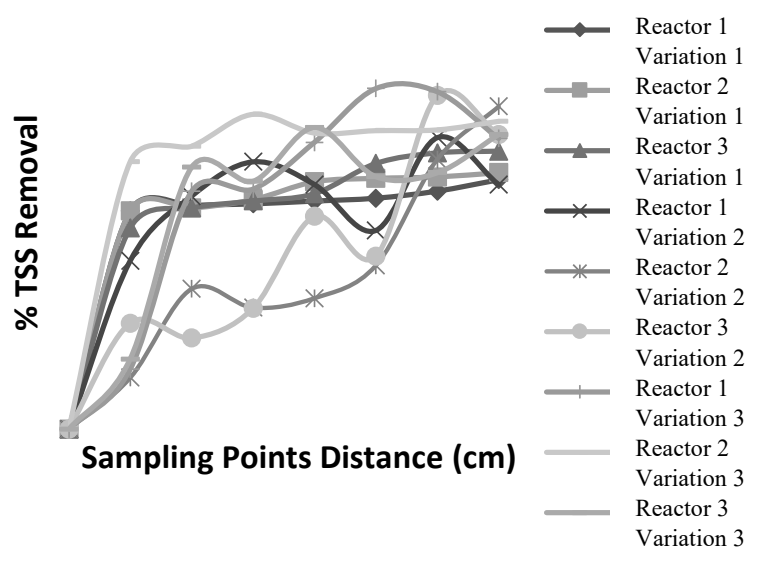

(a)

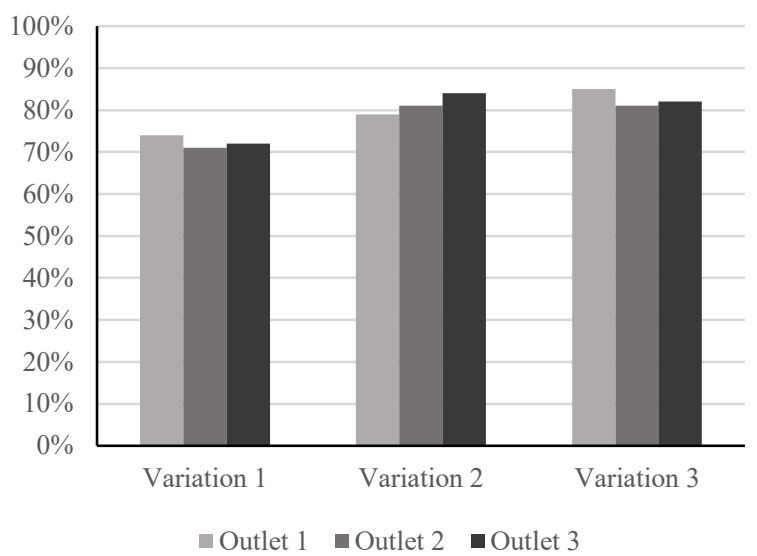

(b)

Figure 5. TSS Removal in preliminary test in (a) different sampling point $(\mathrm{cm})(\mathrm{b})$ three variation of HRT

efficiency in all three variations of the experimental concentration, where the highest efficiency was $79 \%$ at HRT 2.7 hours with a concentration influent $75 \mathrm{mg}$ COD/l, and the lowest efficiency of $47 \%$ at $19.4 \mathrm{hr}$ HRT. In this experiment, the variation of HRT of 19.4 hours showed to be the lowest average removal $(50.3 \%)$ compared to HRT of 2.7 hours and 7.7 hours. This might be caused by the slow flowrate of the water which resulting in changes of the flow direction in the media and affects the organic removal process by aerobic microorganisms attached to the media. According to [1] higher water flow velocity occurs in macropores and lower water flow velocity occurs in micropores.

\subsubsection{First order substrate removal model}

In the first order substrate removal model, the $\mathrm{k}_{1}$ value was obtained from the plot line slope $\left(\mathrm{S}_{0}-\mathrm{S}\right) / \mathrm{HRT}$ against S. Figure 7 (a) shows the results of the plot line $\left(\mathrm{S}_{0^{-}}\right.$ $\mathrm{S}$ /HRT against $\mathrm{S}$, and the $\mathrm{k}_{1}$ values for HRT 2.7 hours, 7.7 hours and 19.4 hours are 14.31/day, 10.40/day, and $0.99 /$ day with correlation coefficients of $0.89,0.98$, and 0.94 respectively. The correlation coefficient $\left(R^{2}\right)$ for 2.7 hour HRT indicates that the first order substrate removal model cannot be applied because the level of precision is 
less than the maximum. According to [5], in the first order substrate type removal reaction model, the removal rate is initially high under conditions of high organic content, but progressively slows down as the utilization of organic matter in the system.

\subsubsection{Strover-Kincannon model}

In the Strover-Kincannon model, the $\mathrm{K}_{\mathrm{B}}$ value is obtained from the slope of the plot line V/Q $\left(\mathrm{S}_{0}-\mathrm{S}\right)$ against $\mathrm{V} /(\mathrm{Q} \times$ $\mathrm{S}_{0}$ ). Through linear regression, slope and intercept can be determined. The saturation constant value $\left(\mathrm{K}_{\mathrm{B}}\right)$ and the maximum substrate use rate $\left(\mathrm{U}_{\max }\right)$ are calculated from the line plots in Figure 7 (b) and produce values of $-3728.2 \mathrm{~g}$ 1/day and $-2000 \mathrm{mg}$ COD 1/day for HRT 2, 7 hours, -1860 $\mathrm{gl} /$ day and -1000 $\mathrm{mg}$ COD 1/day for HRT 7.7 hours, $1097.5 \mathrm{~g} \mathrm{l} /$ day and -500 mg COD 1 / day for HRT 19.4 hours These results indicate the removal of substrate by microorganisms during the time of contact and maximum substrate removal by aerobic organisms with respect to time. From the correlation coefficient for HRT 2.7 hours, 7.7 hours and 19.4 hours respectively $0.98,0.99$ and 0.99 , the Strover-Kincannon model can be used to predict behavior and design in the system PFR in this case.

Table 3. Experimental data obtained under steady-state conditions at nine different HRTs

\begin{tabular}{lccccccccc}
\hline \multicolumn{1}{c}{ Parameter } & \multicolumn{1}{c}{ HRT (h) } \\
\cline { 2 - 9 } & $\mathbf{2 . 7}$ & $\mathbf{2 . 7}$ & $\mathbf{2 . 7}$ & $\mathbf{7 . 7}$ & $\mathbf{7 . 7}$ & $\mathbf{7 . 7}$ & $\mathbf{1 9 . 4}$ & $\mathbf{1 9 . 4}$ & $\mathbf{1 9 . 4}$ \\
\hline Operation period (day) & $0-10$ & $11-20$ & $21-30$ & $0-10$ & $11-20$ & $21-30$ & $0-10$ & $11-20$ & $21-30$ \\
Influent COD (mg/l) & 30 & 75 & 180 & 30 & 75 & 180 & 30 & 75 & 180 \\
$\begin{array}{l}\text { Efluent COD (mg/l) } \\
\begin{array}{l}\text { Removal Efficiency COD } \\
(\%)\end{array}\end{array}$ & 13 & 16 & 64 & 13 & 26 & 48 & 16 & 32 & 96 \\
\hline
\end{tabular}

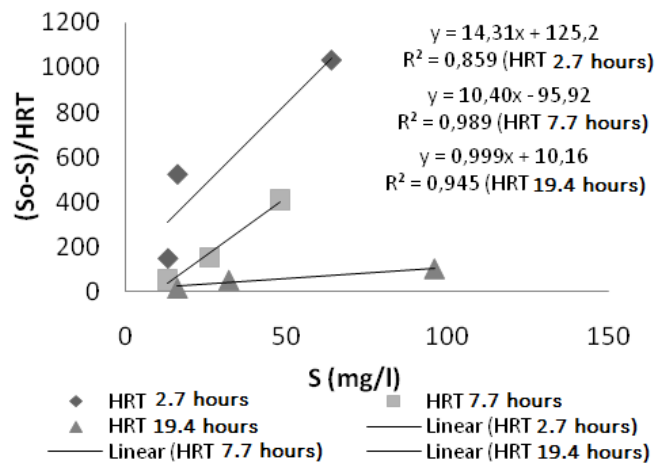

(a)

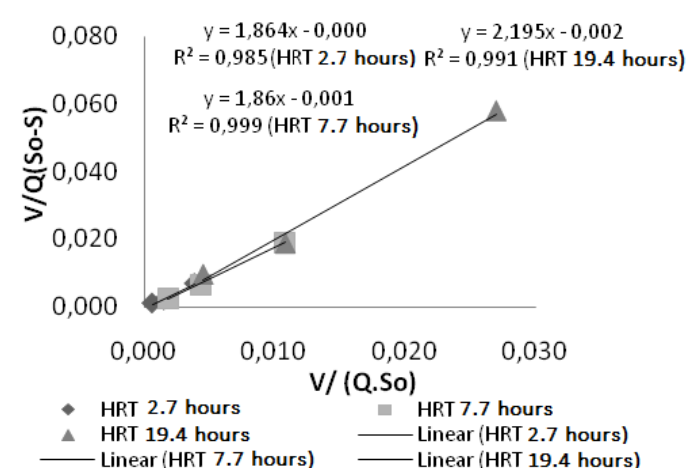

(b)

Figure 7 (a) First order substrate removal model (b)Strover-Kincannon model

\subsection{SEM observations}

SEM analysis used to observe the growing biomass in the media during seeding. Figure 8 shows the appearance of microorganisms that utilize the substrate and nutrient source in the system, where the microorganisms are attached on the surface of the media and covered by filtered clay into the media. Three sample cell size captured in the figure were $5.28 \mu \mathrm{m}, 5.19 \mu \mathrm{m}$ and 5.27 $\mu \mathrm{m}$. The shape of microorganism cells detected on the surface of the artificial support material is coccus. Based on Figure 8, it can be seen that artificial suppport media displays an essentially lacunar structure with crossed fibres and scattered balls [1].

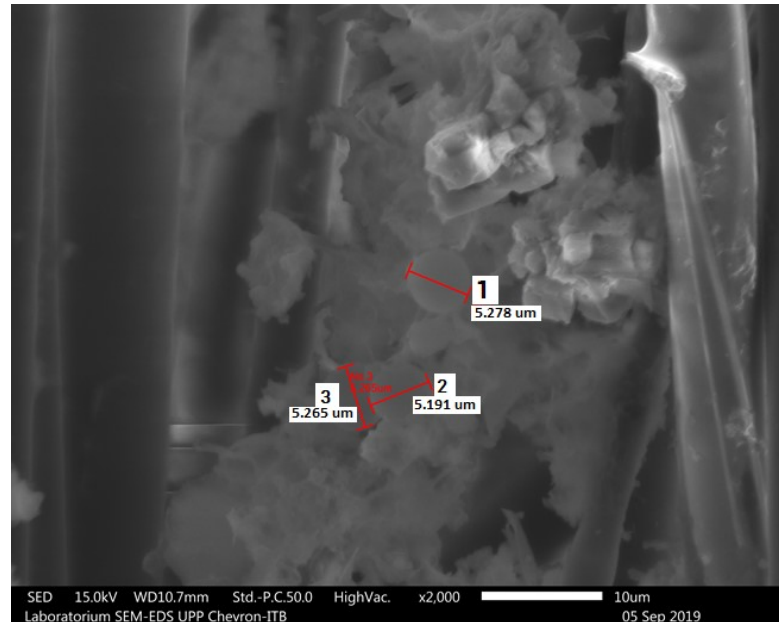

Figure 8 Solid matrix structure using SEM analysis 


\subsection{Water absorption capacity test}

With the residence time of 5 minutes, 3 hours, 24 hours, and 90 hours, the absorption capacity of the media is $24 \%$, $31 \%, 19 \%$, and $23 \%$ for each residence time. The highest efficiency is obtained at a residence time of 3 hours by $31 \%$ of water absorbed into the media. At a residence time of 24 hours there is a decrease in efficiency, it is indicated that at this time the media is starting to experience saturation with aquadest absorption, and efficiency was going back to increase at a residence time of 90 hours. Based on the 2017 Drainblock Catalog, the tested media are cleanblocks that are used for preliminary treatment as biological wastewater treatment, where the surface of the media can allow bacterial colonization. According to [10] in a saturated rockwool slice structure condition, the direction of flow spread horizontally.

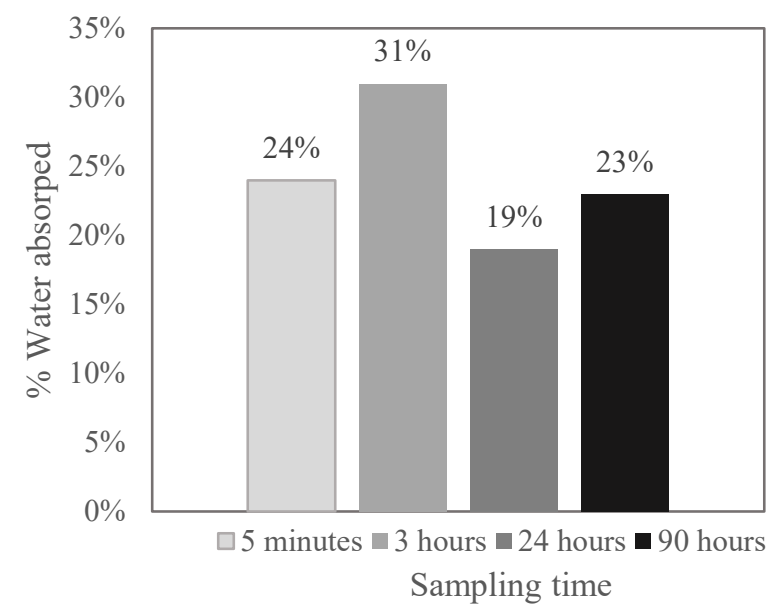

Figure 9. Water absorption capacity

\section{Conclusion}

The removal efficiency of total nitrogen, total phosphate, COD, and TSS in the preliminary test obtained the highest results of $87 \%, 71 \%, 79 \%$, and $85 \%$, respectively. While the removal mechanism of dissolved compound molecules such as total nitrogen, total phosphate, and COD were absorbed by artificial support material, TSS is removed was by filtration mechanism. After three different HRTs were examined, organic removal performance shown that the highest efficiency was $79 \%$ at 2.7 hours HRT with an influent concentration of $75 \mathrm{mg}$ COD/l, and the lowest efficiency by $47 \%$ on HRT 19.4 hours.

The Strover-Kincannon model can be used to predict behavior and design in the PFR system in the case of this experiment with correlation coefficients for HRT 2.7 hours, 7.7 hours and 19.4 hours respectively of $0.98,0.99$, and 0.99 . After seeding,

\section{References}

1. Adrien Wanko, Julien Laurent et al. (2015). Assessment of Rock Wool as Support Material for On-Site Sanitation : Hydrodynamic and Mechanical
Characterization. Environmental Technology ISSN 0959-3330

2. Dirjen Cipta Karya (2007), Petunjuk Teknis Perencanaan. Pembangunan dan Pengelolaan Bidang Ke - PLP-an. Jakarta.

3. Drainblog Katalog. (2017). Sustainable Water Mangement Solutions. Netherlands.

4. Borghei, SM, M Sharbatmaleki, P.Pourrezaie, G. Borghei. (2008). Kinetics of Organic Removal in Fixed-Bed Aerobic Biological Reactor. Bioseource Technology Journal 99 (1118-1124).

5. Mansouri, A.M, A.A.L Zinatizadeh, A. Akhbari. (2014). Kinetic Evaluation of SImultaneous CNP Removal in an up-Flow Aerobic/Anoxic Sludge Fixed Film (UAASFF) Bioreactor. Iranica Journal of Energy and Environment 5 (3): 323-336.

6. Borghei, S.M., Hosseiny, S.H., (2002). Modeling of Organic Removal in a Moving Bed Biofilm Reactor (MBR). Scientia Iranica 9 (1), 53-58.

7. Eckenfelder W Wesley. (2000). Industrial Water Pollution Control [Book]. - New York : McGraw Hill Companies, Inc,. - Third Edition : p. 389. IESBN 0-07-116475-5.

8. Derakhsan, Zahra., et al. (2018). Evaluation of a moving bed biofilm reactor for simultaneous atrazine, carbon and nutrients removal from aquatic environments: modeling and optimization. J.Industrial and Engineering Chemistry.

9. Dewi, Yusriani Sapta and Yanti Buchori. (2016). Penurunan COD, TSS pada Penyaringan Air Limbah Tahu Menggunakan Media Kombinasi Pasir Kuarsa, Karbon Aktif, Sekam Padi, dan Zeolit. Jurnal Ilmiah Satya Negara Indonesia Vo.9 No.1 hal. 74-80.

10. G.De Rijck, E. Schrevens. (1997). Distribution of Nutrients and Water in Rockwool Slabs. Scientia Horticulturae 2 (1998) 27-285

11. De Jaeger, P., (1987). Tuinbouw zonder grond verliest geen grond. Landbouwk. Tijdschrift 2, 1315 